\title{
Što smo naučili u/o nastavi na daljinu?
}

\author{
Ivana Matić \\ Sveučilište u Zagrebu, Ekonomski fakultet, Hrvatska \\ oŠ Ivana Kukuljevića Sakcinskog, Ivanec, Hrvatska \\ e-mail: ivanamati@gmail.com
}

\author{
Draženka Stančić \\ Edward Bernays Visoka škola, Zagreb, Hrvatska \\ oŠ Ivana Kukuljevića Sakcinskog, Ivanec, Hrvatska \\ e-mail:drazenka.stancic@gmail.com
}

SAŽETAK Pandemija koronavirusa značajno je promijenila naše živote, pa tako i obrazovanje. S tradicionalnog oblika naglo se prešlo na nastavu na daljinu (engl. Distance Education) uz trenutno zatvaranje škola i fakulteta, što je vrlo brzo ukazalo na nedostatak domaćih istraživanja te definicije nastave na daljinu. Prema nekima, riječ je o nastavi koja podrazumijeva (a)sinkrono učenje, pri čemu su nastavnici i učenici fizički udaljeni (Pryor i sur., 2020.) te samostalno i/ili vođeno učenje. Nastava na daljinu nije novost. Najprije dopisničkog, kasnije internetskog tipa, svrha joj je bila omogućiti pristup kvalitetnom obrazovanju onima koji ga nemaju iz različitih razloga (zaposlenje, život u ruralnim područjima i dr.) (Davis i Roblyer, 2005.). Unatoč brojnim prednostima, istraživanja ističu da je kod takve nastave učenički neuspjeh češći u usporedbi s onom tradicionalnom (Zucker i Kozma, 2003.). Glavni cilj ovog rada istražiti je stav učenika prema nastavi na daljinu, njihov uspjeh te postoje li aspekti nastave na daljinu povezani s učeničkim uspjehom. Za potrebe istraživanja konstruiran je poseban upitnik na temelju intervjua o stavovima $\mathrm{i}$ iskustvima u nastavi na daljinu tijekom predistraživanja $s$ grupom učenika, a u glavnom istraživanju sudjelovalo je 213 učenika od petog do osmog razreda. Rezultati su pokazali da učenici imaju pozitivne stavove prema nastavi na daljinu i da redovito izvršavaju svoje zadatke, međutim isto tako postoje aspekti kojima nisu zadovoljni, primjerice količina zadaće i društvena izoliranost. Također je zaključeno da s duljinom trajanja nastave na daljinu dolazi do smanjenja razine učeničkog znanja te da postoje aspekti nastave koji su povezani s uspjehom učenika.

Ključne riječi: nastava na daljinu, novi aspekti nastave, uspjeh u nastavi, aspekti uspjeha, pozitivan i negativan stav učenika o nastavi na daljinu. 


\section{Uvod}

Kada se govori o internetskoj nastavi, odnosno nastavi na daljinu, potrebno je imati na umu da to nije nova forma nastave, već da takav oblik obrazovanja datira značajno u prošlost (čak u 19. stoljeće), no bio je značajno drugačijeg formata. Najprije je to bila nastava dopisničkog tipa kako bi se svima pokušalo omogućiti jednako obrazovanje (ponajprije visoko), naročito onima iz udaljenijih i ruralnih područja te onima koji nisu mogli priuštiti boravak u sveučilišnim gradovima. Takav oblik nastave karakterizira asinkrona komunikacija između profesora i studenata, koji su fizički udaljeni te svu komunikaciju ostvaruju dopisničkim putem. U tom slučaju povratna informacija nastavnika odnosno studenta nije trenutačna, već značajno vremenski odmaknuta.

Pedesetih godina dvadesetog stoljeća pojava radija i televizije olakšava dostupnost sadržaja široj populaciji te čini edukaciju na daljinu pristupačnijom. Kao takva ostaje aktualna sve do razvoja nove tehnologije i pojave interneta, koji predstavlja velik skok u protoku informacija i komunikaciji na daljinu, čime započinje sasvim novo doba nastave na daljinu. Razvoj komunikacije putem interneta nudi sve više prilika za obrazovanje, a ključna prednost jest brža interakcija, brzina povratnih informacija, sve lakši i svrsishodniji nadzor studenata bez obzira na fizičku razdvojenost profesora i studenata/učenika te njihovu geografsku udaljenost. Sve bržom digitalizacijom, sve dostupnijim i raširenijim internetom, pristup sadržaju postaje gotovo neograničen, nastava postaje izrazito interaktivna (na temelju e-mailova, internetskih stranica, raznih aplikacija...), a povratna informacija trenutačna, bez nužne blizine sudionika obrazovnog procesa. Privlačnost internetske generacije nastave leži upravo u činjenici da su informacije dostupne u svakom trenutku i da se komunikacija odvija u tom istom trenutku bez nužne fizičke blizine te da ju je moguće postići bez nužnih putovanja. Zanimljiv je podatak da korporativni sektor značajno investira u programe obrazovanja na daljinu, pa tako primjerice IBM, Kodak i drugi ulažu čak 40 milijardi dolara godišnje (McIsaac i Gunawardena, 1996).

Sve brži razvoj tehnologije i njezina primjena u obrazovne svrhe iziskuje nužnu prosmatramo obrazovanjem i cjeloživotnim učenjem. Nastava na daljinu nije jednostavno poučavanje preko elektroničkih medija u kojem sudionici nisu na istom mjestu i vremenu, ona je mnogo više od toga te postavlja nove zahtjeve i pred nastavnike i pred učenike, istovremeno pružajući mnoge prednosti. $S$ obzirom na novu realnost u hrvatskom obrazovnom sustavu trebali bismo govoriti o potrebnim pedagoškim i metodološkim promjenama jer nastava na daljinu više nije samo budućnost, nego je postala svakodnevica na svim vertikalama obrazovanja.

S obzirom na to da su se već gotovo dvije nastavne godine (u trenutku pisanja ovog rada) odvile na daljinu, potrebno je ispitati što se u proteklo vrijeme događalo. Kao i 
cijelo društvo, hrvatsko se obrazovanje suočilo $s$ naglom promjenom. Nastavnici su se našli u novoj situaciji i formi poučavanja, za koju nisu sustavno obučavani. Tako su došle do izražaja individualne karakteristike samih pojedinaca, odnosno kako se tko snašao u trenutnoj situaciji. Sudeći po rezultatima, većina se učitelja dobro snašla, no to je sve uvelike ovisilo o tome kakva je individualna spremnost pojedinca na promjene, individualna želja za učenjem, individualna sposobnost za korištenje moderne tehnologije i slično. Pri prelasku na obrazovanje putem interneta i sam je nastavnik postao učenikom, budući da je najprije morao istražiti mogućnosti obrazovanja na daljinu, dostupne alate te kako se koriste kako bi naposljetku za njihovu upotrebu osposobio svoje učenike. Osim spomenutih tehnoloških faktora, suočeni smo bili sa socijalnom komponentom izoliranosti: nastavnika od kolega odnosno učenika od vršnjaka i nastavnika. Iako su karantena i društvena izoliranost u tom trenutku bile nužne mjere za kontrolu širenja virusa, značajno su utjecale na naše mentalno zdravlje i blagostanje. Društvena izolacija ne samo da povećava rizik od psiholoških poremećaja već je povezana s rastom osjetljivosti i demencije za $50 \%$ (NA, 2020.) $)^{1}$. Novija su istraživanja pokazala da uskraćivanje potrebe za socijalizacijom aktivira isti dio mozga koji reagira na potrebu za hranom, što znači da osobe koje su prisilno društveno izolirane žude za socijalizacijom jednako kao što i gladna osoba žudi za hranom (Tomova i sur., 2020.).

Iako moderna tehnologija donosi nebrojene prednosti unatoč udaljenosti sudionika nastavnog procesa, upravo ta razdvojenost i tehnički uvjeti u velikom broju slučajeva predstavljaju dodatne izazove. Oni su vidljivi naročito kod mlađih uzrasta. Učenici rijetko mogu samostalno i bez poteškoća pristupiti cjelokupnom sadržaju internetske nastave (Benjamin, 2021.), a isto tako im nedostaje tehnološko obrazovanje, pa je potrebna pomoć roditelja, koji postaju ključni faktor u obrazovanju. Osim edukacijskotehnoloških, u nastavi na daljinu ističe se i uloga društveno-razvojnih čimbenika. Za uspjeh u nastavi na daljinu potrebna je društvena podrška, a važnu ulogu ima osjećaj pripadanja (Alonzo Dias i Blazquez, 2009.; Marsap i Narin, 2009.; Pike i sur., 2011.; Hew, 2014. i dr.), dok je „psihološka udaljenost“ navedena kao jedan od čimbenika neuspjeha učenika (Wolcott, 1996.).

Iako ovaj oblik obrazovanja nije novost, ni u prvom valu epidemije kao ni na prijelazu u drugu školsku godinu nisu konzultirana postojeća istraživanja i spoznaje o nastavi na daljinu kako bi se poboljšalo njezino provođenje i podigla kvaliteta. $S$ obzirom na sve navedeno te s ciljem modernizacije školstva, u budućnosti se na takav oblik nastave ne može više gledati kao na nešto prolazno ili ga shvaćati kao privremeno rješenje, već ga je potrebno istraživati, a znanstvene zaključke implementirati u nastavne kurikule i planove na razini države ili barem na razini pojedinih škola.

${ }^{1}$ National Academies of Sciences, Engineering, and Medicine. 2020. 


\section{Istraživanja nastave na daljinu}

Sukladno činjenici da nastava na daljinu u svijetu postoji znatno duže nego u Hrvatskoj, jednako se tako dugo i istražuje. Cilj je takvih istraživanja pretežito ispitati čimbenike te prediktore uspjeha u nastavi na daljinu, vrlo često kako bi se spriječilo osipanje broja polaznika/učenika, odnosno zadržala njihova motivacija za obrazovanjem na daljinu. Tako su se u istraživanjima kao prediktori uspjeha studenata/učenika u nastavi na daljinu istakli dob, samoprocjena vlastitog znanja, dostupnost računala (Robyler i Davis, 2008.), stilovi učenja, postignuće, potreba za znanjem (Wang i Newlin, 2000.), motivacija, samodisciplina, vrijeme provedeno u nastavi (Waschull, 2005.; Robyler i Davis, 2008.), bolje vještine u korištenju tehnologije (Maki i Maki, 2002.; Pillay, Irving i McCrindle, 2006.) te prosjek ocjena (Brauer, Abrami i Surkes, 2004.; Robyler i Davis, 2008.).

U Hrvatskoj jedino istraživanje nastave na daljinu čiji su rezultati javno objavljeni provode Jokić i Ristić-Dedić u lipnju 2020. godine. U sklopu projekta „Obrazovne aspiracije učenika u prijelaznim razdobljima hrvatskog osnovnoškolskog obrazovanja: priroda, odrednice i promjene (COBRAS)“ ispituju zadovoljstvo učenika nastavom na daljinu. U istraživanju je sudjelovalo 923 učenika sedmog razreda iz 23 škole. Sudionici su nastavu ocijenili prosječnom ocjenom 3,14. Čak $88 \%$ učenika tvrdi da s lakoćom koristi digitalne uređaje, a polovica $(52,3 \%)$ da ih rado koristi. Takvi rezultati svjedoče o sklonosti učenika prema korištenju digitalnih uređaja. Iako rado koriste modernu tehnologiju, učenici navode kako su izrazito opterećeni, i to količinom zadataka u kratkom vremenskome roku koje dobivaju u nastavi na daljinu. Kod usporedbe nastave u učionicama i internetske nastave učenici ističu da imaju podjednako dobre odnose s nastavnicima u oba slučaja, no ipak tvrde da je razumljivost sadržaja bolja u učionici $(52,3 \%)$.

\section{Prikaz provedenog istraživanja}

Istraživanje o nastavi na daljinu provedeno je u dva dijela: 1) predistraživanje i 2) glavno istraživanje. Predistraživanje je obuhvaćalo upitničko ispitivanje učenika otvorenim pitanjima o njihovom stavu prema nastavi na daljinu, na temelju čega je sastavljen upitnik za provedbu glavnoga istraživanja.

\subsection{Predistraživanje}

U predistraživanju je sudjelovalo 15 učenika sedmog razreda, $s$ kojima se u aplikaciji Microsoft Teams razgovaralo o prednostima i nedostacima nastave na daljinu te njihovom dojmu o dotada provedenoj nastavi uz osvrt na ono što im se najviše, a što najmanje sviđa, gdje nailaze na poteškoće, koliko vremena troše na nastavu na daljinu 
i slično. Učenici su u realnome vremenu dobili pitanja u spomenutoj aplikaciji te su pisali svoje odgovore, na temelju kojih su im postavljenja i dodatna pitanja.

Nakon obrade odgovora istaknulo se kako učenici radije uče u školi nego u nastavi na daljinu te smatraju da bolje i kvalitetnije uče kada su u učionici.

Učenik A: Meni se puno više svida nastava u školi, jer vidim svoje prijatelje i sva gradiva su mi puno jasnija.

Učenik B: Gradiva nisu dovoljno objašnjena u online nastavi.

Učenik C: Iskreno, puno mi je lakše shvatiti gradivo kad smo u školi, a i ljepše mi je zbog drustva.

Učenik E: U online nastavi neke predmete jednostavno mi sami moramo obradivati i učiti.

Učenici u nastavi na daljinu ističu količinu zadaće kao velik nedostatak, slično kao i u istraživanju Jokić i Ristić-Dedić (2020.).

Učenik F: Malo vecím dijelom mi se ne svida jer ako neki učitelj ima Zoom sat, mi na njemu obradujemo gradivo i onda nam daju još puno zadataka; ne svida mi se količina zadataka.

Učenik D: Kad je nastava na daljinu meni treba puno više vremena da sve napravim nego kad smo u školi.

Također navode kako je predavanje uživo korisno jer tada mogu u realnom vremenu čuti učitelja i pitati ga ako nešto ne razumiju.

Učenik A: U online nastavi mi se sviđa zoom, jer možemo pitati sve što ne razumijemo ili nešto što nas zanima.

Učenik B: Gradiva nisu dovoljno objašnjena jer iz dosta predmeta nemamo zoom sastanke.

Učenik D: Na online nastavi mi se svidaju video pozivi jer možemo pitati što nam nije jasno.

Učenik E: Kada već radimo na daljinu smatram da bi trebali imati uživo sastanke, evo barem meni to pomaže.

Učenici su u odgovorima također hvalili svoje nastavnike i njihov trud u nastavi na daljinu te kao njezine dobre strane isticali samostalnu organizaciju vremena i općenito samostalnost.

Učenik A: Naravno da je puno teže raditi samostalno kod kuće, ali barem ćemo naučiti biti samostalni.

Učenik C: Inače kao i svi ostali zahvalna sam svim učiteljima koji se trude da bi mi sve razumjeli. 
Učenik D: Svi znamo da je puno teže raditi kod kuće nego u školi, ali ipak to ima i jednu dobru stranu, a to je naučit biti samostalni. Možda bi mogao biti video poziv iz malo težih predmeta, ali zadovoljna sam i ovako jer se učitelji stvarno trude.

Učenik E: Svi učitelji su veoma brižni te ih pohvaljujem.

Učenik F: Naravno da mi se škola uživo više svida, ali smatram i da ovo može pridonijeti bar malom poboljšanju tijekom ove situacije. Naravno svi učitelji se trude nam sve najbolje objasniti $i$ to mi se svida.

$\mathrm{Na}$ temelju dobivenih odgovora može se zaključiti da su učenici ozbiljno shvatili nastavu na daljinu te da se trude kao i da su svjesni truda svojih učitelja. Unatoč tome smatraju da je nastava kvalitetnija u školi i razredu kada su okruženi prijateljima i kada nastavnik predaje gradivo, dok za internetsko okruženje rješenje vide u videopozivima u realnom vremenu jer tada mogu pitati učitelje ono što ne razumiju, a ne da samostalno obrađuju gradivo. Količinu zadaće ističu kao nedostatak, napominjući da nastavnici nisu svjesni koliko im zadaće zadaju nakon videopoziva. No smatraju da taj oblik nastave ima i svoje prednosti, posebice kada je riječ o samostalnosti i organizaciji vremena.

\subsection{Glavno istraživanje}

$\mathrm{Na}$ temelju dobivenih učeničkih iskaza sastavljen je upitnik o nastavi na daljinu, čija primjena kod sudionika viših razreda predstavlja glavno istraživanje. Glavno je istraživanje provedeno putem interneta. Kod prikupljanja podataka pomogli su razrednici i učitelji informatike tako da su učenike poticali na sudjelovanje.

\subsection{Cilj istraživanja $\mathbf{i}$ istraživačka pitanja}

Glavni ciljevi istraživanja bili su ispitati kakav je stav učenika prema aspektima nastave uvjetovanima novim modelom učenja na daljinu, je li tijekom nastave na daljinu došlo do smanjenja razine znanja učenika te jesu li neki od aspekata povezani s boljim uspjehom učenika.

S tim u skladu postavljena su i sljedeća istraživačka pitanja:

1. Kakav je stav učenika prema novim aspektima nastave na daljinu?

2. Je li tijekom nastave na daljinu došlo do napretka ili pada u znanju?

3. Postoje li i koji su to aspekti nastave na daljinu povezani $s$ uspješnijim učenjem?

U istraživanju se krenulo od pretpostavke da postoje brojni aspekti tog oblika nastave o kojima je potrebno ispitati učenički stav te saznati pridonose li oni negativnome ili pozitivnome kontekstu učenja. Također se pretpostavlja da se tijekom nastave na daljinu razina znanja učenika smanjila te da postoje aspekti nastave na daljinu koji su povezani s boljim uspjehom učenika. 


\subsection{Sudionici istraživanja}

U ovome istraživanju sudjelovalo je 213 učenika viših razreda osnovne škole. Prošle školske godine 2019./2020. nastavnu su godinu završili po C modelu, što znači da su od početka pandemije sudjelovali u nastavi isključivo na daljinu, dok su u prvom polugodištu tekuće školske godine (2020./2021.) imali nastavu po B modelu, u kojem je jedan razred bio podijeljen u dvije grupe koje su se rotirale po danima, pri čemu je jedna bila na nastavi u školi, a druga je grupa u to vrijeme imala nastavu na daljinu. Najviše je bilo sudionika iz šestog razreda $(\mathrm{N}=89)$, dok je sudionika sedmog $(\mathrm{N}=$ $61)$ i osmog razreda $(N=63)$ bilo podjednako. Nešto je više bilo učenica $(N=113)$ od učenika $(\mathrm{N}=110)$, a nastavu informatike pohađaju gotovo svi učenici $(\mathrm{N}=194)$.

\subsection{Instrument}

U glavnom istraživanju korišten je internetski upitnik pod nazivom „Nastava na daljinu i ja“. Upitnikom su najprije prikupljeni opći podaci ispitanika poput spola, razreda, uspjeha na kraju prošle školske godine i na kraju prvog polugodišta te idu li na izbornu nastavu informatike. Podaci o nastavi na daljinu prikupljani su u sedam tematskih kategorija: 1) što je za mene nastava na daljinu (NND), 2) NND i moje vrijeme, 3) NND i alati, 4) gradivo i zadaće u NND, 5) radno okruženje u NND, 6) moje znanje u NND te 7) moj stav o NND. Prikupljeni učenički odgovori obrađeni su u statističkom programu JASP 0.14.1.0., a za njihovu obradu korištena je deskriptivna i inferencijalna statistika.

\section{Rezultati}

U ovom dijelu rada prikazani su rezultati dobiveni obradom podataka prema postavljenim istraživačkim pitanjima. Najprije su opisani aspekti nastave na daljinu, uključujući učeničke stavove prema njoj, zatim kakav je bio učenički uspjeh u dva razdoblja nastave na daljinu - na kraju prošle školske godine, odnosno nakon potpunog zatvaranja te na kraju prvog polugodišta ove nastavne godine, a na kraju poglavlja slijedi prikaz aspekata nastave na daljinu za koje se pokazalo da su povezani s boljim uspjehom učenika.

\subsection{Aspekti nastave na daljinu}

Tradicionalna nastava, koja podrazumijeva fizičku blizinu učenika i učitelja, boravak u istom prostoru tijekom nastavnog sata te komunikaciju u realnome vremenu, uslijed potpunog zatvaranja (engl. lockdown) u takvom se obliku više nije mogla izvoditi, te se održavala na daljinu, odnosno preko dostupnih elektroničkih uređaja i programa. U 
najširem pogledu, nastava na daljinu odnosi se na fizičku udaljenost učenika i učitelja, poučavanje preko poslanih materijala, najčešće asinkrono te bez trenutnih povratnih informacija, a uključuje internetsku komunikaciju. Koji su to aspekti nastave na daljinu postali sastavni dio obrazovanja sudionika istraživanja u proteklih pola godine (prošle školske godine i tijekom prvog polugodišta tekuće školske godine) slijedi u daljnjem prikazu.

\subsubsection{Oblici nastave na daljinu}

Ovim je istraživanjem zabilježeno osam različitih oblika nastave koje su koristili nastavnici tijekom dvaju obrazovnih blokova nastave na daljinu. To su bili: 1) predavanje u realnome vremenu preko dostupnih aplikacija poput Zooma i Teamsa, 2) slanje nastavnih materijala za prepisivanje u bilježnicu preko razrednog tima, 3) nastava putem učiteljeve ili neke druge videolekcije, 4) nastava putem interaktivnih materijala i igrica, 5) kombinacija slanja materijala i predavanja u realnome vremenu, 6) slanje dokumenta u programu Word s popisom zadaća koje učenici moraju obaviti, 7) obrnuta učionica: nakon proučenih digitalnih sadržaja i razgovora o njima učenici izvršavaju zadaće i prezentiraju rezultate i 8) slanje popisa stranica iz nastavnih materijala (knjiga, radna bilježnica...) koje učenici moraju obraditi kod kuće.

Sudionike istraživanja tražilo se da ocjenama od jedan do pet procijene koji su od navedenih oblika nastave najučinkovitiji za njihovo učenje, odnosno u kojem im je obliku nastave učenje bilo najlakše. Među prisutnim oblicima nastave na daljinu kao najučinkovitije forme odabrali su: predavanja u realnome vremenu $(76,53 \%)$, nastavu putem interaktivnih materijala i igrica $(79,42 \%)$ te kombinaciju slanja materijala i predavanja u realnome vremenu $(67,14 \%)$.

\subsubsection{Ciklus pandemije i obrazovnih razdoblja}

S obzirom na to da su istraživanjem obuhvaćena dva perioda pandemije, očekivalo se da će doći do određenih promjena u samim oblicima nastave. Jedan je razlog taj da su učitelji nakon prvog zatvaranja imali iskustva i znali što je bilo uspješno, a što manje uspješno u provedbi nastave na daljinu, a s druge strane bolje su se upoznali $s$ mogućnostima nastave na daljinu i dostupnim alatima. U ovom se istraživanju, međutim, pokazalo da je do promjene u načinu poučavanja, odnosno do promjene u obliku nastave na daljinu došlo tek kod dva do tri nastavna predmeta prelaskom iz petog u šesti razred (32,8\%), šestog u sedmi (40\%) i iz sedmog u osmi razred $(36,51 \%)$. U istraživanju se također zaključilo da se kvaliteta vođenja nastave na daljinu razlikuje od učitelja do učitelja, a s tom se tvrdnjom slaže $72,77 \%$ učenika. Učenici također smatraju da bi učenje bilo lakše da svi predmeti imaju jednak ili sličan oblik nastave $(86,34 \%)$ te da učitelji uglavnom koriste iste alate $(82,73 \%)$. Takve rezultate potvrđuje i jedan komentar učenika, koji piše: 
Koristimo previše digitalnih alata koji ponekad ni ne rade zbog loše internetske veze. Dobivamo puno toga za nauciti i napisati, a i neki nam učitelji daju previše domaće zadaće na različitim digitalnim alatima za koje većinom nemam dosta vremena da je napravim.

Istraživanjem se ustanovilo da se tijekom šest mjeseci nastave na daljinu koristilo 29 različitih alata za održavanje nastave na daljinu, izvršavanje zadataka, izradu domaću zadaće, projekata i/ili učenje. Iako je riječ o velikoj količini primijenjenih alata, kojima su se i učitelji i učenici morali naučiti koristiti, učenici navode da im raznovrsnih alata nije bilo ni previše ni premalo $(67,07 \%)$, pri čemu tek jedna trećina učenika smatra da ih je bilo previše, no ipak polovica učenika $(50,23 \%)$ smatra da im je lakše koristiti nove alate ako im učitelj objasni njihovo korištenje umjesto da ga moraju sami proučiti. U ovom je istraživanju izdvojeno 15 najčešće korištenih alata u nastavi na daljinu kako bi se prikazala raznovrsnost, ali i raspon informatičke informiranosti sudionika istraživanja (tablica 1).

Tablica 1.

Prikaz najčešće korištenih alata i njihova čestoća uporabe u nastavi na daljinu

\begin{tabular}{|c|c|}
\hline Alat & Čestoća uporabe (N učenika) \\
\hline Microsoft Teams & 211 \\
\hline Zoom & 207 \\
\hline Word & 193 \\
\hline PowerPoint & 187 \\
\hline Padlet & 167 \\
\hline Microsoft Forms & 113 \\
\hline E-mail & 93 \\
\hline Wakelet & 76 \\
\hline Sway & 75 \\
\hline Google Forms & 58 \\
\hline Viber & 57 \\
\hline Google Meet & 55 \\
\hline Google Classroom & 46 \\
\hline Google Sites & 43 \\
\hline Learning Apps & 37 \\
\hline
\end{tabular}

Potrebno je napomenuti da se ukupna komunikacija svih nastavnika, stručnih suradnika i učenika odvijala preko programa Microsoft Teams, stoga je očekivano najzastupljeniji program kojim se služe sudionici istraživanja. Drugi najzastupljeniji program je Zoom, koji je najvećim dijelom uveden u tekućoj školskoj godini, nakon čega očekivano slijede Word i PowerPoint. 


\subsubsection{Angažiranost učenika te izvršavanje zadataka i zadaća u nastavi na daljinu}

Ovim se istraživanjem također željelo dobiti uvid u aktivnost sudionika u nastavi na daljinu u pogledu vremenske i motivacijske uključenosti te u izvršavanje zadataka u odnosu na redovitost, razloge izvršavanja zadataka te vremensku opterećenost.

Vrstu svog aktivnog sudjelovanja učenici su ocjenjivali ocjenama od jedan do pet. Najveći broj sudionika istraživanja tvrdi da aktivno sudjeluje u nastavi na daljinu $(88,73$ $\%)$ te navode kako uče i tijekom nastave na daljinu, ali i nakon nje $(62,91 \%)$, a isto tako velik broj njih smatra da se izrazito trudi u nastavi na daljinu $(78,4 \%)$. Iz takvih rezultata vidljivo je da su učenici angažirani u nastavi na daljinu bez obzira na broj alata, raznovrsnost nastave od predmeta do predmeta te da se trude razumjeti nastavno gradivo i naučiti ga.

Osim aktivnosti sudionika ispitana je i njihova motivacija za učenje na daljinu te motivacija za učenje u školi, odnosno po tradicionalnom modelu. Učenici su svoju motiviranost za pojedini oblik nastave trebali ocijeniti ocjenama od jedan do pet. Rezultati su pokazali kako su učenici motiviraniji za učenje u školi, što je vidljivo na srednjim vrijednostima u tablici 2.

Tablica 2.

Razlika u motivaciji za učenje u školi i za učenje u online nastavi

\begin{tabular}{|c|c|c|c|}
\hline & $M$ & $t$ & $p$ \\
\hline Motivacija za učenje na daljinu & 3.23 & \multirow{2}{*}{6.64} & \multirow{2}{*}{$<.001$} \\
\hline Motivacija za učenje u školi & 3.89 & & \\
\hline
\end{tabular}

Kako bi se ispitalo je li razlika u njihovoj motivaciji statistički značajna, provedena je $t$-test analiza. Rezultati su pokazali statistički značajnu razliku u korist učenja u školi, što znači da su učenici značajno manje motivirani za učenje na daljinu negoli za učenje u školi, unatoč prethodno istaknutoj angažiranosti i aktivnosti u nastavi na daljinu.

Unatoč smanjenoj motivaciji, izrazito velik broj učenika redovito piše zadaće na daljinu $(86,85 \%)$. Kao razloge toga navode da ih zadaća zanima $(56,34 \%)$, da žele učiti $(51,64 \%)$ te da smatraju da je to važno $(53,52 \%)$, što svjedoči o navedenoj aktivnosti. Unatoč tim pozitivnim rezultatima, također velik postotak njih navodi da zadaću radi jer ne želi dobiti minus, odnosno bilješku u e-dnevnik (59,62\%), a jedna četvrtina navodi da radi jer ne želi da ih učiteljica javno proziva kako nemaju domaću zadaću. U tom velikom postotku učenika koji rade domaću zadaću postoje i oni koji je rade, ali ne razumiju ništa od zadatka $(38,02 \%)$, dok nešto manji broj učenika prepisuje od drugih (15,02\%). Tek najmanji i gotovo zanemariv broj učenika ne radi zadaću te se 
nada da ih učitelj neće prozvati $(5,16 \%)$ i ne rade je jer ih ne zanima $(1,41 \%)$. Ono što se istaknulo među otvorenim odgovorima jest da učenici dobivaju previše zadaće, odnosno zadataka povrh nastave preko videopoziva ili videolekcija, pa tako pišu: „Topli prijedlog da se daje manje zadaća“; „Mislim da bi bilo bolje da ako idemo na nastavu na daljinu da ne dobivamo tolko zadaće da netrebamo biti cijeli dan za računalom"; „Htio bih čim više Zoom-ova i da iz svakog predmeta dobijemo toliko zadaće da bi mogli stići rješiti zadaću i iz drugih predmeta.“; „Učitelji bi trebali međusobno komunicirati da nam ne daju previše zadaće, jer ponekad nisu svjesni koliko zadaće imamo iz drugih predmeta.“; „Voljela bih da imamo Zoom satove iz svih predmeta i nakon satova dobivamo malo zadaće, kao i u školi, a ne da dobijemo još duplo više zadaće."

Sudionike istraživanja također se pitalo koliko vremena dnevno provode za računalom u nastavi na daljinu. To se vrijeme odnosilo na predavanja preko videopoziva, proučavanje materijala, pisanje zadaća te rješavanje poslanih/zadanih zadataka. Najvećim dijelom učenici dnevno potroše pet do šest sati za učenje $(31,92 \%)$, odnosno tri do četiri (27,23\%). Nešto veći broj sati u nastavi na daljinu provodi znatno manji broj učenika $(19,25 \%)$, i to sedam do osam, a osam sati i više provodi tek $9 \%$ učenika, odnosno njih 20.

\subsubsection{Okružje učenja u nastavi na daljinu}

Kao što je već spomenuto, ovaj novi oblik nastave donosi prostornu odvojenost učenika i nastavnika, čime se mijenja mjesto učenja i poučavanja; učenici su kod kuće, a nastava se odvija preko mreže, što stvara potrebu za dodatnom prilagodbom i izazove tehničke te prostorno-socijalne prirode.

Istraživanjem se također željelo ispitati na koje su tehničke poteškoće sudionici nailazili za vrijeme odvijanja nastave na daljinu. Rezultati su pokazali da velik broj učenika ima lošu ili slabiju internetsku vezu $(84,51 \%)$ te da pri tome nije zanemarivo ni stanje računala. Navode da koriste staro, odnosno sporije računalo $(34,74 \%)$, a također ističu i povremeno problematične/nestabilne aplikacije na kojima se odvija nastava $(27,70 \%)$. Iako je škola sudionicima ovog istraživanja osigurala tablete, učenici i njih navode kao nepouzdane, odnosno imali su tehničkih problema i sa školskim tabletima (15,95\%). Zbog navedenih tehničkih poteškoća s kojima se susreo velik broj sudionika istraživanja opravdano se može promišljati o upitnosti kvalitete njihove uključenosti u nastavu na daljinu.

Uz izazove koje donosi tehnologija, ovim se istraživanjem ispitalo i kakvi su prostorno-socijalni uvjeti u kojima učenici prate nastavu, odnosno radni prostor te uključenost roditelja i obitelji u nastavu na daljinu. Pozitivni su rezultati da učenici najvećim dijelom nastavu na daljinu prate u svojoj sobi $(78,40 \%)$ te za svojim radnim stolom $(53,05 \%)$, ali isto tako drugi dio njih nastavu prati u sobi koju dijele $s$ braćom 
(13,62\%), u dnevnoj sobi $(13,63 \%)$, a sličan broj njih navodi kako mijenja radno mjesto ovisno o prilikama (13,15\%). Najmanji broj nastavu najčešće prati u kuhinji $(5,16 \%)$ ili tek kada dođu na red od braće i sestara $(2,82 \%)$. Iako polovica učenika ima svoj radni prostor u kojem može postići mir i rutinu u radu, druga polovica učenika nema svoj prostor za učenje.

S obzirom na preseljenje nastave iz škole u obiteljski prostor logično je pretpostaviti da će se promijeniti i uloga roditelja u samoj nastavi. Oni su u nastavi na daljinu, a naročito prošle školske godine za vrijeme potpunoga zatvaranja, bili svakodnevno izloženi nastavnom procesu. Zbog toga se ovim istraživanjem također ispitalo koje su to sve uloge roditelji imali za vrijeme nastave na daljinu u proteklom razdoblju. Učenicima su bile ponuđene izjave o ulogama roditelja, od kojih su mogli odabrati više njih, no također su mogli samostalno dopisati što još njihovi roditelji rade, a što nije bilo predviđeno upitnikom. Učenici tvrde kako roditelji najvećim dijelom vode brigu o tome da učenici naprave svu potrebnu zadaću $(43,66 \%)$, no također im pomažu oko razumijevanja gradiva $(29,58 \%)$. Otprilike podjednak broj roditelja pomaže učenicima oko organizacije vremena za učenje i izvršavanje zadataka (26,29\%), provjerava njihovu zadaću prije nego je pošalju nastavniku $(25,35 \%)$ te im pomaže s informatičkom tehnologijom (22,54\%). Rezultati su, međutim, pokazali i da ima situacija gdje roditelji ne pomažu u nastavi na daljinu, a razlozi su, kako učenici navode, jer žele da učenici budu samostalni $(26,76 \%)$ i jer ni oni sami ne razumiju gradivo odnosno zadaću $(16,43 \%)$.

\subsubsection{Stav učenika prema nastavi na daljinu}

Jedan od ciljeva istraživanja bio je ispitati učenički stav o nastavi na daljinu. Kako bi se navedeno ispitalo, učenicima su ponuđeni razlozi za pozitivan odnosno negativan dojam o nastavi na daljinu na temelju predistraživanja intervjuom $s$ grupe učenika. Od ponuđenih su mogli odabrati nekoliko, a ne samo jedan. Na taj način došlo se do podataka o tome što se učenicima kod nastave na daljinu izrazito sviđa te što im se najmanje sviđa. i što za vrijeme nastave mogu piti i jesti (29,34\%). U ovom obliku nastave vide priliku da pokažu sve svoje znanje u korištenju multimedije (29,38\%), a izrazito im se sviđa da imaju priliku samostalno organizirati svoje radno vrijeme i izvršavanje zadanih zadataka $(46,9 \%)$. Što se tiče nastavnika, učenicima se sviđa što im se mogu javiti u svako doba dana $(54,5 \%)$, pozitivnim smatraju kada nastavnici koriste Zoom, odnosno videopozive $(46,9 \%)$ ili snimaju videolekcije $(33,65 \%)$ te cijene trud nastavnika da im pojasne gradivo na daljinu $(37,65 \%)$. 
Iako učenici vole pokazivati svoje umijeće u korištenju multimedije, u nastavi im se na daljinu ipak ne sviđa što komuniciraju samo putem računala i mobitela $(46,45 \%)$, što nisu okruženi svojim prijateljima $(60,19 \%)$ i nisu u razredu $(45,97 \%)$. Zbog toga i navode da nemaju motivacije za učenjem na taj način (46,45\%). Također kritiziraju što neka nastavna gradiva nisu objašnjena uživo, nego ih samo prepisuju (30,33\%), a kao najnegativniji aspekt nastave na daljinu ističu previše domaće zadaće $(61,61 \%)$.

Imajući na umu fizičku udaljenost te potencijalne prilike za neodgovorno ponašanje u nastavi, u upitnik je uvršten jedan odlomak pod nazivom „Moje male tajne“, a koji je ispitivao „isključuju“ li se učenici u nastavi na daljinu i ne prate nastavu, rade li nešto drugo dok nastavnik predaje, uključuju li se samo kada ih nastavnik prozove $\mathrm{i}$ slično. Na temelju dobivenih odgovora vidljivo je da učenici uglavnom ne rade takve stvari te da su većinom odgovorni u nastavi na daljinu. Iz nastave se isključi i ne prati je tek $12,68 \%$ učenika, dok polovica njih $(49,30 \%)$ to nikada ne radi. Iako se pretpostavljalo da bi se neki učenici mogli uključivati u nastavu tek kada nastavnik proziva, to radi tek zanemariv postotak $(8,92 \%)$, dok njih $61,03 \%$ to nikada nije napravilo. Veći je broj, međutim, onih koji se često probude tek par minuta prije početka nastave $(24,4 \%)$, no ipak je znatno više onih koji to ne rade $(44,13 \%)$. Iako se u nastavi na daljinu ponekad bilježilo ometanje učenika igranjem po aplikacijama u kojima se odvija nastava, to radi tek neznatan broj učenika (2,35\%), dok gotovo svi $(92,96 \%)$ to ne rade. Isto tako vrlo rijetko za vrijeme nastave pokreću razgovore s prijateljima iz razreda putem opcije za chat $(6,57 \%)$, ali navode da to ponekad i rade $(36,62 \%)$, dok većina ipak to ne radi $(56,81 \%)$.

U ispitivanju stavova sudionika također ih se tražilo da navedu tri asocijacije o nastavi na daljinu koje im prve padnu na pamet. Učenici su naveli ukupno 227 različitih asocijacija, od kojih je 49 pozitivnih, kao što su igrice, više slobodnog vremena, dom i druge, 83 su neutralne, poput računala, Zooma, interneta i slično, dok je najviše onih negativnih, čak 94, od kojih se naročito ističe asocijacija vezana uz domaću zadaću, odnosno da je imaju puno.

\subsection{Učenički uspjeh u nastavi na daljinu}

Uspjeh učenika u ovome istraživanju mjeren je njihovim završnim ocjenama na kraju prošle školske godine (2019./2020.) te na kraju prvog polugodišta ove školske godine (2020./2021.). U oba slučaja učenici postižu vrlo dobar uspjeh. Vrlo je velik broj odličnih i vrlo dobrih ocjena, pri čemu se na kraju prvog polugodišta ove školske godine broj odličnih učenika smanjuje, a povećava broj vrlo dobrih i dobrih učenika, što je vidljivo u tablici 3 . 
Tablica 3.

Ocjene učenika na kraju prošle školske godine i prvog polugodišta tekuće školske godine

\begin{tabular}{|l|c|c|c|c|c|}
\hline & & odličan & vrlo dobar & dobar & dovoljan \\
\hline kraj školske godine 2019./2020. & $N$ & 70 & 46 & 12 & 0 \\
\hline kraj 1. polugodišta 2020./2021. & $N$ & 63 & 50 & 14 & 1 \\
\hline
\end{tabular}

Smanjenje odličnih, a povećanje nižih ocjena ogleda se i u srednjoj ocjeni učenika, koja je niža na kraju prvog polugodišta tekuće nastavne godine (tablica 4).

Tablica 4.

Razlika razine znanja/uspjeha učenika na kraju prošle školske godine i na kraju prvog polugodišta tekuće školske godine

\begin{tabular}{|l|c|c|c|}
\hline & $M$ & $t$ & $p$ \\
\hline kraj školske godine 2019./2020. & 4,427 & & \multirow{2}{*}{2,641} \\
\cline { 1 - 2 } kraj 1. polugodišta 2020./2021. & 4,329 & & 0,009 \\
\hline
\end{tabular}

Kako bi se provjerilo je li spomenuta razlika u znanju učenika statistički značajna, provedena je $t$-test analiza. Analizom se ustanovilo da, iako dolazi do smanjenja razine znanja učenika s trajanjem nastave na daljinu, ona nije statistički značajna.

\section{3. Čimbenici uspjeha u nastavi na daljinu}

S obzirom na specifičnosti nastave na daljinu i naročito njezino trajanje, jedan od ciljeva istraživanja bio je provjeriti postoje li aspekti ovog oblika nastave koji su povezani $s$ boljim uspjehom učenika. Kako bi se pronašli aspekti nastave povezani s uspjehom učenika, provedene su $t$-test i korelacijske analize svih ispitanih aspekata. Rezultati su pokazali da zaista postoje oni koji su povezani s boljim ocjenama učenika. To su spol, rutina, motivacija, vrijeme, samoprocjena vlastitog zalaganja, aktivnost te vrsta same održane nastave.

Kao što je prethodno navedeno, spol učenika aspekt je po kojem se učenici razlikuju u uspjehu u nastavi na daljinu, pri čemu su djevojčice uspješnije od dječaka. Njihov je bolji uspjeh u ovom obliku nastave zabilježen i na kraju prošle školske godine i na kraju prvog polugodišta tekuće nastavne godine. Isto tako ta je razlika statistički značajna, što prikazuje tablica 5 . 
Tablica 5.

Razlika uspjeha učenika prema spolu

\begin{tabular}{|c|c|c|c|c|c|c|}
\hline & spol & $N$ & $M$ & $S D$ & $t$ & $p$ \\
\hline \multirow{2}{*}{$\begin{array}{l}\text { kraj školske godine } \\
2019 . / 2020 .\end{array}$} & muško & 100 & 4,260 & 0,733 & \multirow{2}{*}{3,499} & \multirow{2}{*}{, 001} \\
\hline & žensko & 112 & 4,575 & 0,579 & & \\
\hline \multirow{2}{*}{$\begin{array}{l}\text { kraj 1. polugodišta } \\
2020 . / 2021 \text {. }\end{array}$} & muško & 100 & 4,130 & 0,747 & \multirow{2}{*}{3,893} & \multirow{2}{*}{,001 } \\
\hline & žensko & 112 & 4,504 & 0,656 & & \\
\hline
\end{tabular}

Idući aspekt po kojem se učenici razlikuju u svom uspjehu jest stečena odnosno postignuta rutina u nastavi na daljinu. U obradu rezultata uključeni su samo učenici koji su naveli da su je stekli i oni koji su naveli da nisu stekli navike u nastavi na daljinu, kako bi mogla biti ispitana njihova razlika. Potrebno je napomenuti kako je ipak više onih učenika koji su stekli rutinu u ovom obliku nastave, a upravo se ona pokazala kao statistički značajna razlika kada je u pitanju njihov uspjeh (tablica 6).

Tablica 6.

Razlika uspjeha učenika prema usvojenoj rutini rada

\begin{tabular}{|l|c|c|c|c|c|c|}
\hline & rutina & $\boldsymbol{N}$ & $\boldsymbol{M}$ & $\boldsymbol{S D}$ & $\boldsymbol{t}$ & $\boldsymbol{p}$ \\
\hline \multirow{2}{*}{$\begin{array}{l}\text { kraj školske godine } \\
\text { 2019./2020. }\end{array}$} & $\mathrm{da}$ & 96 & 4,583 & 0,610 & \multirow{2}{*}{4,083} & \multirow{2}{*}{$<, 001$} \\
\cline { 2 - 5 } $\begin{array}{l}\text { kraj 1. polugodišta } \\
\text { 2020./2021. }\end{array}$ & $\mathrm{da}$ & 96 & 4,531 & 0,660 & \multirow{2}{*}{4,938} & \multirow{2}{*}{$<001$} \\
\cline { 2 - 5 } & ne & 32 & 3,875 & 0,648 & & \\
\hline
\end{tabular}

Rutina se pokazala kao aspekt uspjeha učenika u nastavi na daljinu i na kraju prošle školske godine te na kraju prvog polugodišta ove školske godine. Takav nalaz potvrđuje potrebu za stvaranjem rutine kako bi učenici bili uspješniji i u novom obliku nastave.

Korelacijskom analizom pronađeni su dodatni aspekti provedene nastave na daljinu koji su povezani s boljim uspjehom učenika u oba perioda nastave na daljinu (tablica 7). Tako se pokazalo da su učenici koji su motiviraniji za nastavu na daljinu ujedno i uspješniji u samoj nastavi. Isto tako, učenici koji provode više vremena u nastavi na daljinu postižu bolje rezultate, kao i učenici koji svoj rad i zalaganje procjenjuju boljim. S tim u skladu, učenici koji provode manje vremena u nastavi na daljinu, lošije procjenjuju svoj rad i zalaganje te nisu motivirani za nastavu na daljinu postižu slabiji uspjeh u oba slučaja, odnosno i na kraju prošle školske godine i na kraju prvog polugodišta ove godine. Bolji uspjeh značajno korelira s aktivnim sudjelovanjem učenika u nastavnom procesu na daljinu, koji uključuje i učenje tijekom i nakon 
nastave te redovito izvršavanje zadataka koje daje nastavnik. Sukladno tome, učenici koji nisu aktivni u nastavi na daljinu postižu očekivano slabije rezultate.

Tablica 7.

Korelacije aspekata nastave na daljinu i uspjeha učenika

\begin{tabular}{|l|c|c|}
\hline & $\begin{array}{c}\text { kraj školske } \\
\text { godine } \\
\mathbf{2 0 1 9 . / 2 0 2 0 .}\end{array}$ & $\begin{array}{c}\text { kraj } \mathbf{1 .} \\
\text { polugodišta } \\
\mathbf{2 0 2 0 . / 2 0 2 1 .}\end{array}$ \\
\hline Motivacija za nastavu na daljinu & $0,24^{* * *}$ & $0,24^{* * *}$ \\
\hline Vrijeme provedeno u nastavi na daljinu & $0,29^{* * *}$ & $0,35^{* * *}$ \\
\hline Samoprocjena vlastitog zalaganja i rada u nastavi na daljinu & $0,55^{* * *}$ & $0,60^{* * *}$ \\
\hline Aktivno sudjelovanje & $0,47^{* * *}$ & $0,52^{* * *}$ \\
\hline Učenje tijekom i nakon nastave na daljinu & $0,35^{* * *}$ & $0,38^{* * *}$ \\
\hline Redovito pisanje zadaće i izvršavanje zadataka & $0,36^{* * *}$ & $0,32^{* * *}$ \\
\hline Predavanja preko videopoziva u realnome vremenu & $0,37^{* * *}$ & $0,30^{* * *}$ \\
\hline Nastava putem interaktivnih materijala i igrica & $0,19^{* * *}$ & 0,13 \\
\hline Nastava putem videolekcije & $0,19^{* *}$ & $0,14^{*}$ \\
\hline Obrnuta učionica & $0,19^{* *}$ & $0,17^{*}$ \\
\hline Kombinacija slanja materijala i videopoziva u realnome vremenu & $0,23^{* * *}$ & $0,31^{* * *}$ \\
\hline
\end{tabular}

${ }^{*} \mathrm{p}<, 05 ;{ }^{* *} \mathrm{p}<, 01 ;{ }^{* * *} \mathrm{p}<, 001$

Vrlo zanimljivi rezultati koji su dobiveni ispitivanjem odnosa aspekata nastave na daljinu i uspjeha učenika u njoj odnose se na vrste izvedbe same nastave. S obzirom na to da nije bilo jasno propisanih pravila na koji se način nastava mora izvoditi, prisutni su bili različiti oblici, ovisno o nastavniku (v. Poglavlje 3.1). Ovim se ispitivanjem, međutim, pokazalo da ipak postoje oni koji su povezani s boljim uspjehom učenika u nastavi na daljinu, a to su: predavanja u realnome vremenu preko videopoziva, nastava preko snimljenih videolekcija, obrnuta učionica, kombinacija slanja nastavnih materijala i videopoziva u realnome vremenu te nastava putem interaktivnih materijala i igrica, no posljednji oblik nastave povezan je s uspjehom učenika samo prošle školske godine, dok na kraju prvog polugodišta više nije povezan s boljim uspjehom učenika.

\section{Rasprava}

$\mathrm{U}$ ovome istraživanju krenulo se od ispitivanja stavova učenika prema novim i drugačijim aspektima nastave od one u tradicionalnome smislu. Istraživanjem se najprije zaključilo da postoji osam različitih oblika nastave koji su zastupljeni tijekom cijelog ispitivanjem obuhvaćenog perioda nastave na daljinu. Tolika količina raznovrsnih nastavnih principa za učenike mlađeg uzrasta, kao što su osnovnoškolci, predstavlja potencijalnu opasnost za izostanak stjecanja rutina i navika u radu. Rutina odnosno navike učenja predstavljaju određene vještine za optimalno postizanje u uspjeha u 
školi. Stalna promjena oblika nastave mogla bi utjecati na kvalitetu samog obrazovanja i na kraju učenikova znanja. $S$ obzirom na to da učenici izdvajaju tri oblika nastave $s$ kojima povezuju vlastiti napredak i bolje učenje (predavanja u realnome vremenu, nastavu putem interaktivnih materijala i igrica te kombinaciju slanja materijala i predavanja u realnome vremenu), iz njihovih odgovora može se pretpostaviti da je učenicima potrebna sinkrona komunikacija s nastavnikom te spomenuta interaktivnost (kako bi imali osjećaj napretka). Tu pretpostavku potkrepljuje i stav koji navodi velika većina učenika, a to je da bi im učenje bilo lakše ako bi svi nastavnici imali jednak ili sličan oblik nastave.

Povrh istaknutog broja različitih metoda nastavnog rada na daljinu, kao još jedan njezin negativan aspekt ističe se i količina raznovrsnih alata koji se koriste. U samo pola godine ove vrste nastave učenici koriste čak 29 različitih alata, što je izrazito velik broj, naročito ako svaki od tih alata moraju najprije postaviti na računalo te naučiti koristiti kako bi pratili nastavu ili napravili dobiveni zadatak ili domaću zadaću. Da su i oni sami toga svjesni vidljivo je u stavu, koji ima više od $80 \%$ učenika, da bi im učenje bilo uspješnije kada bi nastavnici uglavnom koristili istovrsne alate. Ukoliko već trebaju koristiti nove alate, polovina učenika navodi kako bi im bilo značajno lakše da ih u njihovu uporabu uputi nastavnik, a ne da sami moraju istraživati kako se alat koristi. Iz navedenih rezultata vidljivo je da su učenici svjesni što bi za njihov napredak bilo dobro čak i u ovom novom obliku nastave s kojim su tek nedavno upoznati. Moglo bi se stoga pretpostaviti da bi manji broj različitih oblika nastave te smanjenje broja alata rasteretili učenike i njihovo vrijeme te bi na taj način lakše stekli rutinu i radne navike, za koje se ovim istraživanjem zaključilo da su povezane s boljim uspjehom.

Najveći dio učenika provodi u nastavi na daljinu pet do šest sati. Na temelju toga može se reći da provode slično vrijeme u internetskoj nastavi kao što bi ga provodili i u školi. No u ovom se slučaju mora imati na umu da se radi o nastavi pred ekranom, odvojeno od društva, dok su u školi ipak okruženi vršnjacima te uključeni u socijalizaciju sa svojom generacijom.

Što se tiče aktivnosti učenika u nastavi na daljinu i izvršavanja obaveza, može se zaključiti kako su oni izrazito angažirani bez obzira na broj alata, različite oblike nastave od predmeta do predmeta te da se trude razumjeti gradivo i naučiti ga. Skoro $90 \%$ učenika redovito piše zadaću, a gotovo $80 \%$ tvrdi da se izrazito trudi u nastavi na daljinu, što znači da su učenici svjesni kako je cilj i ove vrste nastave učenje te da su pritom usmjereni na vlastitu produktivnost i obrazovanje bez obzira na izazove s kojima su suočeni. Takvi rezultati govore o vrlo pozitivnom stavu učenika prema nastavi općenito te o osjećaju odgovornosti usprkos izazovnom i ponekad zahtjevnom karakteru nastave na daljinu. No, unatoč njihovoj angažiranosti i marljivosti, više od polovine ispitanika navodi da domaću zadaću radi jer ne želi dobiti bilješku u e-dnevnik ili minus, a jednako velik broj učenika navodi da je radi, no pri tome je uopće ne razumije. 
Takvi su rezultati zabrinjavajući iz nekoliko razloga. Najprije zbog količine vremena utrošenog u izradu zadataka jedino s ciljem da bi se izvršila zadaća, a ne s ciljem postizanja napretka, vježbanja gradiva ili učenja, pri čemu bi to isto vrijeme, kada bi nastava bila bolje organizirana, mogli iskoristiti za učenje. Drugi zabrinjavajući razlog, kako učenici navode, prevelika je količina zadataka koja im se daje. Iz perspektive nastavnika ona je potrebna za ponavljanje, vježbanje ili čak kontrolu sudjelovanja učenika u nastavi, međutim iz učeničke perspektive vidimo da se to ne događa, već da je rade kako bi ispunili formu, a ne nešto naučili. Veliku količinu zadaće kao negativan aspekt nastave na daljinu navode i Jokić i Ristić-Dedić (2020.) u svojem istraživanju. Može se stoga reći da je to svakako aspekt koji treba uzeti u obzir prilikom organizacije nastave na daljinu na razini škola, ali i samog predmeta.

Ovim radom ispitani su i aspekti vezani uz okruženje učenja, poput tehničkih uvjeta i onih prostorno-socijalnih, budući da su to neke od najvećih promjena u obrazovanju na daljinu. Rezultati su pokazali kako učenici imaju najviše problema upravo s ključnim tehnološkim uvjetima nastave, a to su internetska veza i računalo. Iako učenici većinom nastavu prate u svojim sobama, drugi je dio učenika prati u sobi koju dijeli $s$ braćom, u dnevnoj sobi, kuhinji ili mijenja radno mjesto ovisno o prilikama. Navedeni aspekti mogu itekako ometati formiranje već spominjanih rutina i navika učenja, koje su ovim istraživanjem dokazano povezane s uspjehom u školi. Učenik koji stalno ima problema s internetskom vezom pa ga „izbacuje“ iz poziva ili koji stalno mora seliti svoje radne materijale i računalo ovisno o prilikama te nema radno mjesto koje povezuje s procesom učenja i radom mogao bi slabije napredovati, teže se usredotočiti na samu nastavu te zbog toga vrlo lako izgubiti volju za učenjem. Ako se spomenute situacije ponavljaju iz dana u dan, učenik već samu nastavu na daljinu može povezivati $s$ navedenim negativnim situacijama te brže odustajati.

Od socijalnih aspekata ispitana je još i uloga roditelja, koji su u ovom trenutku postali aktivniji oko nastave no ikada. Učenici tvrde da njihovi roditelji najviše vode brigu oko toga jesu li napravili domaću zadaću te je provjeravaju prije slanja nastavniku, a nezanemariv ih broj pomaže učenicima oko korištenja informatičke tehnologije. Drugi pak dio roditelja ne pomaže oko nastave jer, kako tvrde, žele da učenici postanu samostalni ili jer ni oni sami ne razumiju gradivo. Iz dobivenih rezultata može se pretpostaviti kako je i tu vidljiv naglasak na zadaću koju učenici dobivaju u nastavi na daljinu jer joj pažnju pridaju i sami roditelji te se angažiraju oko njezine izrade, slanja i provjere.

Prethodno navedeni negativni aspekti nastave na daljinu (previše različitih vrsta nastave, previše digitalnih alata, prevelika količina zadaće koja se radi zbog ispunjavanja obaveza, problemi s internetskom vezom, starim računalom i prostornim uvjetima) ogledaju se i u motivaciji učenika. Rezultati su pokazali kako su učenici značajno manje motivirani za nastavu na daljinu nego za tradicionalni oblik nastave u školi. Može 
se pretpostaviti da su razlog toj niskoj motivaciji za nastavu na daljinu upravo prethodno nabrojani negativni aspekti. Dobivene rezultate potvrđuje i istraživanje Jokić i Ristić-Dedić (2020.), koji su istražujući stav učenika prema nastavi na daljinu također otkrili kako su učenici motiviraniji za nastavu u školi.

Pretpostavka o smanjenoj razini znanja uslijed trajanja nastave na daljinu pokazala se točnom, odnosno ispitivanje je pokazalo da u prvom polugodištu ove nastavne godine dolazi do slabijeg uspjeha učenika. Što je točan razlog takvih rezultata teško je pouzdano tvrditi, međutim može se pretpostaviti da je došlo do zasićenja učenika nastavom na daljinu, njezinim promjenjivim oblicima i količinom zadaće, a isto tako da su je zbog odvojenosti od nastavnika, svojih vršnjaka i uobičajenih modela nastave shvaćali manje ozbiljno, kao i da primijenjene metode nastave nisu bile učinkovite za stjecanje znanja na daljinu.

Neosporiva je činjenica, međutim, da obrazovni sustav teži digitalizaciji i da je uslijed pandemije neplanirano proveden najveći eksperiment potpune digitalizacije nastave. Unatoč nedostacima i negativnim aspektima nastave na daljinu, bez nje obrazovanje u doba pandemije ne bi bilo moguće. Potpuni prelazak na poučavanje putem digitalnih medija omogućio je nastavak obrazovanja u vrijeme najveće krize uzrokovane koronavirusom. Za njenog trajanja pokazalo se da učenici rado pokazuju svoje umijeće u korištenju multimedije i da rado koriste dostupne alate. Zbog navedenih činjenica pretpostavka je ovog istraživanja bila da postoje aspekti nastave na daljinu koji su povezani s boljim uspjehom učenika. Analiza dobivenih rezultata potvrdila je pretpostavku istraživanja te pokazala da je bolji uspjeh učenika povezan $s$ vrstom nastave (predavanja u realnome vremenu, nastava preko snimljenih videolekcija, obrnuta učionica, kombinacija slanja nastavnih materijala i videopoziva u realnome vremenu te nastava putem interaktivnih materijala i igrica), stečenom rutinom učenika, vremenom provedenim u internetskoj nastavi, motivacijom za učenje u nastavi na daljinu, aktivnošću učenika te samoprocjenom vlastitog zalaganja. Dobivene rezultate teško je povezati s prethodno provedenim istraživanjima jer ih u hrvatskome obrazovnom kontekstu nema, osim onog koje su proveli Jokić i Ristić-Dedić (2020.), međutim oni nisu tražili aspekte povezane s uspjehom učenika. Od prikazanoga, jedino se pronalaske da su motivacija i vrijeme provedeno u nastavi na daljinu povezani s uspjehom učenika može dovesti u vezu s rezultatima prethodno provedenih istraživanja, gdje su navedeni aspekti nastave dokazani čak kao prediktori uspjeha (Waschull, 2005.; Robyler i Davis, 2008.).

Dobiveni aspekti uspjeha $u$ nastavi na daljinu mogu se povezati $s$ aspektima nastave u učionici. Vidljivo je da je za uspješno obrazovanje potrebna izravna, odnosno trenutna komunikacija između nastavnika i učenika te interaktivna nastava. Isto je tako ključno aktivno sudjelovanje u nastavnom procesu, baš kao i u razredu, za postizanje optimalnih rezultata. Neosporiva je uloga i stečenih rutina te radnih navika, koje zna- 
čajno olakšavaju organizaciju vremena i vlastitog učenja, a time su povezane i s boljim uspjehom.

Prikazani pozitivni aspekti nastave na daljinu povezani $s$ učeničkim uspjehom trebali bi nakon budućih provjera biti sastavni i polazišni dio budućih planova i programa obrazovanja na daljinu ili barem sastavni dio plana kriznog upravljanja pojedine obrazovne ustanove.

\section{Zaključak}

U stvaranju obrazovnih politika nužno je čuti, razumjeti i uzeti u obzir stavove učenika kao krajnjih korisnika obrazovnog sustava, zbog kojih on mora biti promišljen i usklađen s prilikama u kojima se nalaze kako bi se naposljetku ostvarili odgojno obrazovni ciljevi. Potrebno je imati na umu pozitivne strane nastave na daljinu, poput samostalnosti u radu, motiviranosti i želje učenika da koriste nove medije, ali i one negativne, koje su rezultat specifičnosti takve vrste nastave i naglog prijelaza na nju, poput tehničkih problema, previše zadaće i alata pa sve do snižene razine znanja učenika. $\mathrm{Na}$ temelju dobivenih podataka može se promišljati o aktualizaciji postojećeg modela nastave na daljinu ili pak razvijati viziju hibridnog modela nastave budućnosti.

$S$ obzirom na to da je prisilno proveden vrlo vrijedan eksperiment, dobivene su vrijedne informacije o tome koje bi se pokazane prednosti digitalizacije i kako mogle implementirati u nastavu budućnosti. Kako bi se ona kvalitetno uklopila u nastavu uz nužnu povremenu fizičku blizinu nastavnika i mlađih učenika, kao zaključak ovog istraživanja predlaže se napraviti sporazum na nivou obrazovne ustanove koji uključuje: 1) definiranje broja alata (aplikacija) koji će se koristiti tijekom zaokruženog obrazovnog perioda ( $\breve{S} G, A G), 2$ ) definiranje gornje granice količine zadaće za učenike i rokove za njihovo izvršavanje, 3) zaokruženo vrijeme koje učenici i učitelji mogu podnijeti tijekom nastave na daljinu po predmetu ( $45 \mathrm{~min}$ je previše) i po danu, 4) pravovremeno definiranje tjednog ili dnevnog rasporeda po razredu uz obaveznu suradnju nastavnika, 5) edukaciju o uporabi alata (aplikacija) za učenike planiranu na početku školske godine i ravnomjernije raspodijeljenu po predmetima i vještijim učiteljima, 6) organiziranje osobne mreže učenja (engl. Personal Learning Network), kolegijalne podrške i dijeljenja primjera dobre prakse unutar obrazovne ustanove, 7) suradnju i komunikaciju nastavnika u izradi planova i programa radi usklađivanja količine opterećenja učenika te 8) plansku implementaciju pozitivnih elemenata nastave u buduće obrazovne kurikulume.

Budući modeli nastave mogli bi predstavljati kombinaciju najboljih iskustava provedene internetske nastave i tradicionalnog obrazovanja, stoga rezultati ovog istraživanja predstavljaju korak ka stvaranju novoga i učenicima primjerenoga modela nastave na daljinu, a svoj bi puni potencijal ostvarili u povezivanju s perspektivama i stavovima 
nastavnika. Ovo bi istraživanje kao preliminarno trebalo potaknuti daljnja, koja su nužna ako će se u budućnosti zaista razmišljati o integraciji internetske nastave u tradicionalni oblik obrazovanja kakav poznajemo te njenoj digitalizaciji. Sukladno tome nužna su iduća istraživanja kako bi se dali potrebni znanstveni temelji te stvorili metodološki i didaktički okviri ovakve vrste nastave.

\section{Literatura:}

1. Alonzo Diaz, L. and Blazquez Entonado, F. (2009). Are the functions of teachers in eLearning and FacetoFace learning environments really different?. Journal of Educational Technology \& Society, 12 (4): 331-343. https://www.jstor.org/stable/pdf/jeductechsoci.12.4.331.pdf. (Pregledano 9. siječnja 2021.)

2. Benjamin, R. G. (2012). Reconstructing readability: Recent developments and recommendations in the analysis of text difficulty. Educational Psychology Review, 24 (1): 63-88. https://www.researchgate.net/ profile/Rebekah_Benjamin/publication/271640179 Reconstructing_Readability_Recent_Developments_and_Recommendations_in_the_Analysis_of Text Difficulty/links/58bf591092851cd83aa12acd/Reconstructing-Readability-Recent-Developments-and-Recommendations-in-the-Analysis-of-Text-Difficulty.pdf. (Pregledano 10. siječnja 2021.)

3. Davis, N. and Roblyer, M. D. (2005). Preparing teachers for the "schools that technology built": Evaluation of a program to train teachers for virtual schooling. Journal of Research on Technology in Education, 37: 399-409.

4. Hew, K. F. (2014). Promoting engagement in online courses: What strategies can we learn from three highly rated MOOCS. British Journal of Educational Technology, 47 (2): 320-341.

5. Jokić, B. i Ristić-Dedić, Z. (2020). Iskustva i zadovoljstvo učenika 7. razreda online nastavom. Medijsko izvješće. Institut za društvena istraživanja u Zagrebu. Projekt: „Obrazovne aspiracije učenika u prijelaznim razdobljima hrvatskog osnovnoškolskog obrazovanja: priroda, odrednice i promjene (COBRAS)" https://www.scribd.com/document/465070670/Zadovoljstvo-i-IskustvaOnline-Nastavom-7-Razred-IDIZ\#from embed. (Pregledano 10. siječnja 2021.)

6. Marsap, A. and Narin, M. (2009). The integration of distance learning via internet and face to face learning: Why face to face learning is required in distance learning via internet?. Procedia - Social and Behavioral Sciences, 1 (1): 28712878. https://www.sciencedirect.com/science/article/pii/S1877042809005126. (Pregledano 11. siječnja 2021.)

7. McIsaac, M. S. and Gunawardena, C. N. (1996). Distance Education, in: Jonassen, D. H. (Ed.). Handbook of research for educational communications and technology: a project of the Association for Educational Communications and Technology. New York: Simon \& Schuster Macmillan, 403-437. 
8. National Academies of Sciences, Engineering and Medicine. 2020. Social Isolation and Loneliness in Older Adults: Opportunities for the Health Care System. Washington, DC: The National Academies Press. https://www.cdc.gov/aging/ publications/features/lonely-older-adults.html. (Pregledano 11. siječnja 2021.)

9. Pike, G. R.; Kuh, G. D. and McCormick, A. C. (2011). An Investigation of the contingent relationships between learning community participation and student engagement. Research in Higher Education, 52 (3): 300-322.

10. Pryor, J.; Wilson, R. H.; Chapman, M.; Bates, F. (2020). Elementary Educators' Experiences Teaching during COVID-19 School Closures: Understanding Resources in Impromptu Distance Education. Online Journal of Distance Learning Administration, XXIII (4). https://www.westga.edu/ - distance/ojdla/ winter234/pryor young chapman bates234.html. (Pregledano 10. siječnja 2021.)

11. Roblyer, M. D. and Davis, L. (2008). Predicting success for virtual school students: Putting research-based models into practice. Online Journal of Distance Learning Administration, 11 (4). https://www.westga.edu/-distance/ojdla/winter114/ roblyer 114.html. (Pregledano 10. siječnja 2021.)

12. Tomova, L.; Wang, K. L.; Thompson, T.; Matthews, G. A.; Takahashi, A.; Kay M. T.; Saxe R. (2020). Acute social isolation evokes midbrain craving responses similar to hunger. Nat Neurosci, 23: 1597-1605. https:/www.nature.com/ articles/s41593-020-00742-z\#citeas. (Pregledano 11. siječnja 2021.)

13. Wolcott, L. (1996). Distant, but not distanced. A learner-centered approach to distance education. Techtrends, 41 (4): 23-27.

14. Zucker, A. and Kozma, R. (2003). The virtual high school: Teaching generation V. New York: Teachers College Press. 


\title{
What Did we Learn in/about Distance Learning?
}

\author{
Ivana Matić \\ University of Zagreb, The Faculty of Economics \& Business, Croatia \\ Elementary School Ivan Kukuljević Sakcinski, Ivanec, Croatia \\ e-mail: ivanamati@gmail.com \\ Draženka Stančić \\ University College Edward Bernays, Zagreb, Croatia \\ Elementary School Ivan Kukuljević Sakcinski, Ivanec, Croatia \\ e-mail:drazenka.stancic@gmail.com
}

\begin{abstract}
The coronavirus pandemic has significantly changed our lives, and so has our education. From the traditional form, there was a sudden transition to distance education with the current closure of schools and colleges, which very quickly pointed to the lack of research in Coratia about this education type or what is and what is not distance learning. According to some, it is a teaching that involves synchronous learning where teachers and students are physically distant (Pryor, Wilson, Chapman, Bates, 2020) and independent and / or guided learning, and often in the process the teacher becomes a student. Distance learning is not new. First of the correspondent type, later of the online type, the purpose was to provide access to quality education to those who do not have this opportunity for various reasons (employment, life in rural areas, etc.) (Davis and Roblyer, 2005). Despite its many advantages, research points out that student failure is much more common compared to the traditional one (Zucker and Kozma, 2003). The main goal of this paper is to investigate the attitude of students towards distance learning, their success in two moments of teaching and whether there are aspects of distance learning related to their success. For the purposes of the research, a special questionnaire was constructed based on interviews about attitudes and experiences in distance learning with a focus group of students, and 213 students from fifth to eighth grade participated in the main research. The results showed that students' attitudes towards distance learning are positive, that students regularly perform their tasks, but there are also aspects they are not satisfied with, such as the amount of task assigned and social isolation. It was also concluded that with the duration of distance learning there are reduced levels of success and that there are aspects of teaching that are related to student success.
\end{abstract}

Key words: distance learning, new aspects of teaching, success in teaching, aspects of success, positive and negative attitude of students about distance learning. 